\title{
A Chemical Ionization Study of Deuteron Transfer Initiated Propene Loss from Propoxypyridines
}

\author{
Eric S. E. van Beelen, Tineke A. Molenaar-Langeveld, \\ and Steen Ingemann \\ Faculty of Science, Swammerdam Institute for Life Sciences, University of Amsterdam, Amsterdam, \\ The Netherlands
}

\begin{abstract}
The mechanism of propene loss from the metastable $[\mathrm{M}+\mathrm{D}]^{+}$ions of isomeric 2-, 3-, and 4- $n$-propoxypyridines and the related isopropoxypyridines has been examined by chemical ionization (CI) and tandem mass spectrometry in combination with deuterium labeling. The $[\mathrm{M}+\mathrm{D}]^{+}$ions were generated with $\mathrm{CD}_{3} \mathrm{OD}, \mathrm{CD}_{3} \mathrm{CN},\left(\mathrm{CD}_{3}\right)_{2} \mathrm{CO}$, or pyrrole- $\mathrm{D}_{5}$ (listed in order of increasing proton affinity) as the $\mathrm{CI}$ reagent. The results reveal that the deuteron added in the CI process is not interchanged with the hydrogen atoms of the propyl group prior to propene loss from the metastable $[\mathrm{M}+\mathrm{D}]^{+}$ions of the propoxypyridines. The site selective labeling of the $\alpha^{-}, \beta-$, or $\gamma$-position of the propyl group indicates that the $[\mathrm{M}+\mathrm{D}]^{+}$ions of 2 - $n$-propoxypyridine expel propene with formation of an ion-neutral complex composed of a propyl carbenium ion and 2-pyridone. By contrast, the $[\mathrm{M}+\mathrm{D}]^{+}$ions of 3- $n$-propoxypyridine expel propene by: (1) Formation of ion-neutral complexes, and (2) a conventional 1,5-hydride shift from the $\beta$-position of the $n$-propyl group to the ring and/or a 1,2-elimination type process. For the 4-isomer, the results suggest the occurrence of propene loss by a 1,2elimination in addition to the intermediate formation of ion-neutral complexes. Loss of propene with one deuterium atom is the only reaction of the $[M+D]^{+}$ions of the isopropoxypyridines labeled at the $\alpha$-position of the isopropyl group. The results for the isopropoxypyridines labeled with three deuterium atoms at the $\beta$-position are consistent with: (1) The loss of propene by ion-neutral complex formation and the occurrence of a substantial isotope effect in the subsequent proton/deuteron transfer within the complex, and/or (2) the loss of propene by a 1,2-elimination type reaction. (J Am Soc Mass Spectrom 2003, 14, 1166-1176) (c) 2003 American Society for Mass Spectrometry
\end{abstract}

S ite-specific proton affinities (PA) and the occurrence of proton transfer reactions in the absence of solvent molecules are of fundamental importance in mass spectrometry [1-6].

The site of protonation depends not only on the proton affinity of the distinct sites in a molecule, but also on the existence of possible energy barriers for the proton transfer reaction [7-10]. In particular, proton transfer to the aromatic ring can be hindered by a kinetic barrier even though this entity of a substituted benzene is often associated with a higher proton affinity than a substituent such as an OH or OR group [11-18].

Insight into the molecular properties that determine the regioselectivity of proton transfer reactions is also of importance for studies concerned with structure elucidation with the use of Chemical Ionization [1]. This is particularly pertinent as it is often observed that the

Published online August 11, 2003

Address reprint requests to Dr. S. Ingemann, Faculty of Science, Swammerdam Institute for Life Sciences, University of Amsterdam, Nieuwe Achtergracht 166, Amsterdam 1018 WV, The Netherlands. E-mail: ingemann@science.uva.nl initial step in protonation of an organic compound is related directly to the dissociation reactions of the $[\mathrm{M}+$ $\mathrm{H}]^{+}$ions. Furthermore, polyfunctional organic species can show a complex behavior as protonation can occur at distinct sites and nonetheless lead to dissociation by a single process. For example, the metastable $[\mathrm{M}+\mathrm{H}]^{+}$ ions of phenyl $n$-propyl ether are known to dissociate exclusively by propene loss irrespective of the fact that protonation can occur at the phenyl ring as well as at the oxygen atom of the substituent [16, 17, 19-23]. As emphasized in several CI studies of aryl $n$-propyl ethers with deuterium labeled reagents, the metastable $[\mathrm{M}+$ $\mathrm{D}^{+}$ions expel propene molecules that contain the deuteron transferred from the conjugate acid of the CI reagent to the ether in the ion source [16, 17, 19-22]. In previous reports, the incorporation of the deuterium atom from the CI reagent was suggested to involve initial deuteron transfer to the oxygen atom of phenyl $n$-propyl ether and fluorine or methyl substituted analogues $[16,17]$. By contrast, deuteron transfer to the aromatic ring was proposed to result in the loss of a 
propene molecule that contained only the hydrogen atoms of the original propyl group.

In order to obtain more insight into the influence of the initial protonation site on the mechanism of alkene elimination from protonated aromatic ethers, we decided to examine propene loss from a series of isomeric propoxypyridines. The propoxypyridines were chosen as model compounds because it can be anticipated that protonation at the nitrogen atom of the ring is preferred considerably over protonation at the oxygen atom of the substituent. This expectation is corroborated by the calculated proton affinity of the nitrogen atom in 2-hydroxypyridine $\left(\mathrm{PA}=931 \mathrm{~kJ} \mathrm{~mol}^{-1}\right)$, which is $183 \mathrm{~kJ}$ $\mathrm{mol}^{-1}$ higher than the calculated value of the oxygen atom $\left(748 \mathrm{~kJ} \mathrm{~mol}^{-1}\right)$ [24]. In other words, the propoxypyridines offer the possibility to study the loss of propene from aromatic ethers that may be protonated only at the heteroatom of the ring. In addition, the selection of 2-, 3- and 4-propoxypyridines allows an examination of influence of the distance between the protonation site and the substituent on the mechanism of propene loss.

In the studies concerned with propene loss from [M $+\mathrm{D}]^{+}$ions of phenyl $n$-propyl ethers and their derivatives, a number of CI reagent gasses were used in order to generate the ionic species $[16,17]$. In these studies it was shown that the incorporation of the deuterium atom from the $\mathrm{CI}$ reagent in the propene molecule is enhanced if the CI reagent gas has a relatively high proton affinity. For example, the metastable $[\mathrm{M}+\mathrm{D}]^{+}$ ions of phenyl $n$-propyl ether expel $\mathrm{C}_{3} \mathrm{H}_{5} \mathrm{D}$ and $\mathrm{C}_{3} \mathrm{H}_{6}$ in ratio of 18:82 if $\mathrm{CD}_{3} \mathrm{OD}\left(\mathrm{PA}=754 \mathrm{~kJ} \mathrm{~mol}^{-1}\right)$ [25] is the $\mathrm{CI}$ reagent, whereas the ratio between $\mathrm{C}_{3} \mathrm{H}_{5} \mathrm{D}$ and $\mathrm{C}_{3} \mathrm{H}_{6}$ loss is $27: 73$ with $\mathrm{CD}_{3} \mathrm{CN}\left(\mathrm{PA}=779 \mathrm{~kJ} \mathrm{~mol}^{-1}\right)$ [25] as the CI gas [16]. With the purpose of examining the possible influence of the dynamics of the initial deuteron transfer to the propoxypyridines on the ensuing loss of propene, we decided to form the metastable [M $+\mathrm{D}^{+}$ions of the propoxypyridines with $\mathrm{CD}_{3} \mathrm{OD}$, $\mathrm{CD}_{3} \mathrm{CN},\left(\mathrm{CD}_{3}\right)_{2} \mathrm{CO}$ or pyrrole- $\mathrm{D}_{5}$ (listed in order of increasing proton affinity) as the reagent gas.

\section{Experimental}

The Chemical Ionization (CI) spectra and the massanalyzed ion kinetic energy (MIKE) [26, 27] spectra of the (un)labeled propoxypyridines were recorded with the use of a Micromass (Manchester, UK) VG ZAB$\mathrm{HFqQ}$ reverse geometry double focusing hybrid mass spectrometer $[28,29]$. The $\mathrm{CI}$ reagent $\left(\mathrm{CD}_{3} \mathrm{OD}, \mathrm{CD}_{3} \mathrm{CN}\right.$, $\left(\mathrm{CD}_{3}\right)_{2} \mathrm{CO}$, or pyrrole- $\left.\mathrm{D}_{5}\right)$ were mixed with a propoxypyridine in a volume ratio of 9:1. The binary chemical sample was introduced into a combined electron ionization/chemical ionization (EI/CI) source through a heated septum inlet system (temperature $\sim 175{ }^{\circ} \mathrm{C}$ ) until the pressure was in the range of $10^{-5}-10^{-4}$ mbar as measured by an ionization gauge placed in a side arm to the entrance of the diffusion pump situated beneath the ion source housing. A few experiments were also performed at a different total pressure (between $10^{-6}$ mbar and $10^{-4}$ mbar) of the $\mathrm{CI}$ reagent and the propoxypyridine in the combined EI/CI source. The ion source parameters were: Electron energy $70 \mathrm{eV}$, temperature $175-200{ }^{\circ} \mathrm{C}$, ion repeller potential $0-2 \mathrm{~V}$, and acceleration voltage $8 \mathrm{kV}$. Collision-induced Dissociation (CID) experiments were performed with helium as the collision gas and with the reduction of the main beam intensity to $50 \%$.

\section{Materials and Synthesis}

The unlabeled 2-, 3-, and 4-hydroxypyridines, $\mathrm{CH}_{3} \mathrm{CH}_{2} \mathrm{CD}_{2} \mathrm{OH}, \quad \mathrm{CD}_{3} \mathrm{CD}_{2} \mathrm{CD}_{2} \mathrm{OD}, \quad \mathrm{CH}_{3} \mathrm{CD}(\mathrm{OH}) \mathrm{CH}_{3}$ and $\mathrm{CD}_{3} \mathrm{CD}(\mathrm{OD}) \mathrm{CD}_{3}$ were commercially available and used without further purification. The labeled propanols were reacted with $48 \% \mathrm{HBr}$ in water in order to obtain the related bromopropanes. The unlabeled 2-3-, and 4-propoxypyridines and their deuterated analogues were prepared by reacting the 2-, 3-, and 4-hydroxypyridines with sodium ethanolate followed by reaction with an appropriately labeled 1- or 2-bromopropane [30, 31].

\section{$\mathrm{CH}_{3} \mathrm{CD}_{2} \mathrm{CH}_{2} \mathrm{OH}$}

1-propanol labeled at the 2-position was prepared by repeated hydrogen-deuterium exchange of methyl malonic acid with $\mathrm{D}_{2} \mathrm{O}$ to afford DOOCCD $\left(\mathrm{CH}_{3}\right)$ COOD. Decarboxylation of one of the carboxylic groups leading to $\mathrm{CH}_{3} \mathrm{CD}_{2} \mathrm{COOH}$ was followed by reduction of the other carboxylic group by $\mathrm{LiAlH}_{4}$ to give $\mathrm{CH}_{3} \mathrm{CD}_{2} \mathrm{CH}_{2} \mathrm{OH}$ [32].

\section{$\mathrm{CD}_{3} \mathrm{CH}_{2} \mathrm{CH}_{2} \mathrm{OH}$}

1-propanol labeled at the 3-position was prepared by treating $\mathrm{HOOCCH}_{2} \mathrm{COOH}$ with $\mathrm{NaH}$ followed by reaction with $\mathrm{CD}_{3} \mathrm{I}$. Decarboxylation and reduction as described above gave $\mathrm{CD}_{3} \mathrm{CH}_{2} \mathrm{CH}_{2} \mathrm{OH}$.

\section{$\mathrm{CD}_{3}-\mathrm{CH}(\mathrm{OH})-\mathrm{CH}_{3}$}

Grignard reaction of $\mathrm{CD}_{3} \mathrm{MgI}$ with freshly distilled acetaldehyde gave the appropriately labeled 2-propanol.

All ethers were purified by preparative gas chromatography (column: Reoplex 400, temperature $125^{\circ} \mathrm{C}$ ). The identity of the ethers as well as the labeling content $(>99 \%)$ was determined by ${ }^{1} \mathrm{H}$ NMR and EI mass spectrometry.

\section{Results}

Chemical Ionization of the propoxypyridines with one of the selected reagents $\left(\mathrm{CD}_{3} \mathrm{OD}, \mathrm{CD}_{3} \mathrm{CN},\left(\mathrm{CD}_{3}\right)_{2} \mathrm{CO}\right.$ and Pyrrole- $\mathrm{D}_{5}$ ) leads in the ion source to relatively abundant $[\mathrm{M}+\mathrm{D}]^{+}$ions. The $[\mathrm{M}+\mathrm{D}]^{+}$ions of the unlabeled propoxypyridines react on the $\mu$ s time-scale only by the loss of $\mathrm{C}_{3} \mathrm{H}_{6}$ with the formation of $\mathrm{C}_{5} \mathrm{H}_{5} \mathrm{DNO}^{+}$ 


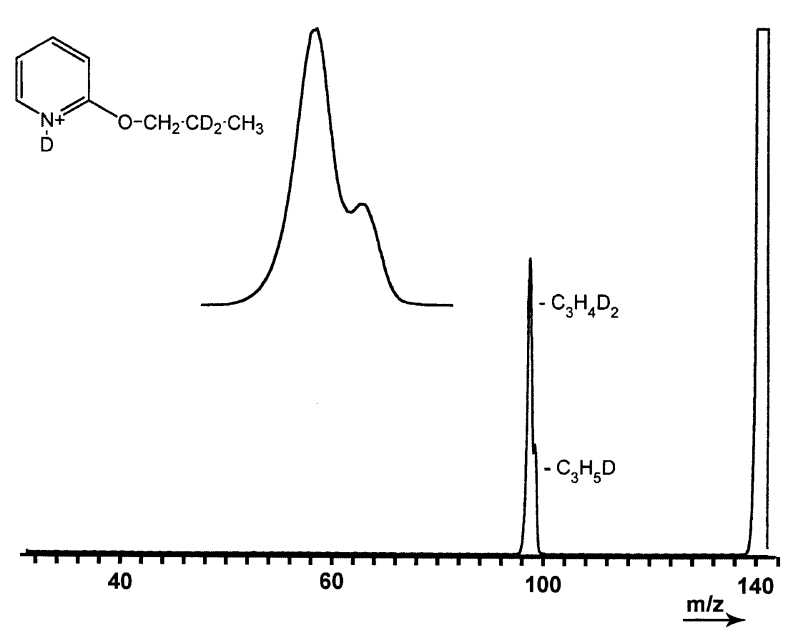

Figure 1. Reactions of the metastable $[\mathrm{M}+\mathrm{D}]^{+}$ions of 2-npropoxypyridine labeled with two deuterium atoms at the $\beta$-position of the propyl group.

ions (eq 1) irrespective of the CI gas. The exclusive loss of $\mathrm{C}_{3} \mathrm{H}_{6}$ from the metastable $[\mathrm{M}+\mathrm{D}]^{+}$ions of the unlabeled ethers reveals that the deuterium atom from the reagent is not involved directly in the dissociation reaction. This is further corroborated by the sole occurrence of the loss of $\mathrm{C}_{3} \mathrm{D}_{6}$ from the metastable $[\mathrm{M}+\mathrm{D}]^{+}$ions of propoxypyridines with a perdeuterated propyl group (vide infra).

$$
\begin{gathered}
\left(\mathrm{C}_{5} \mathrm{H}_{4} \mathrm{~N}\right) \mathrm{OCH}_{2} \mathrm{CH}_{2} \mathrm{CH}_{3} \stackrel{\left[\mathrm{D}_{\mid}^{+}\right]}{\longrightarrow}\left[\mathrm{M}+\mathrm{D}^{+}\right. \\
\longrightarrow \mathrm{C}_{5} \mathrm{H}_{5} \mathrm{DNO}^{+}+\mathrm{C}_{3} \mathrm{H}_{6}
\end{gathered}
$$

\section{n-Propoxypyridines}

Site-specific deuterium labeled n-propoxypyridines were examined subsequently in order to obtain more insight into the origin of the $\mathrm{H}$ atom transferred from the propyl group to the remaining part of the ionized species prior to the expulsion of propene. The presence of two D atoms at the $\alpha$-position of the 2-n-propoxypyridines is observed to lead to the losses of $\mathrm{C}_{3} \mathrm{H}_{5} \mathrm{D}$ and $\mathrm{C}_{3} \mathrm{H}_{4} \mathrm{D}_{2}$ from the metastable $[\mathrm{M}+\mathrm{D}]^{+}$ions (eq 2). The average ratio between the losses of $\mathrm{C}_{3} \mathrm{H}_{5} \mathrm{D}$ and $\mathrm{C}_{3} \mathrm{H}_{4} \mathrm{D}_{2}$ is determined to be $24: 76$ by measuring the area of the Gaussian shaped metastable peaks (see Figure 1).

$$
2-\left(\mathrm{C}_{5} \mathrm{H}_{4} \mathrm{~N}\right) \mathrm{O}\left(\mathrm{CD}_{2} \mathrm{CH}_{2} \mathrm{CH}_{3}\right) \stackrel{\left[\mathrm{D}^{+}\right]}{\longrightarrow}
$$

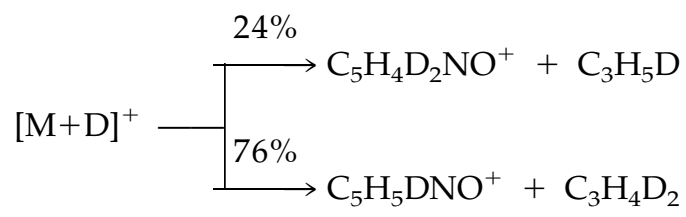

The same ratio between the losses of $\mathrm{C}_{3} \mathrm{H}_{5} \mathrm{D}$ and $\mathrm{C}_{3} \mathrm{H}_{4} \mathrm{D}_{2}$ is observed for the $[\mathrm{M}+\mathrm{D}]^{+}$ions of the $\left[\beta, \beta-\mathrm{D}_{2}\right]-2-n$-propoxypyridines as for the $\left[\alpha, \alpha-\mathrm{D}_{2}\right]$-labeled species (see Table 1). For the $\left[\gamma, \gamma, \gamma-\mathrm{D}_{3}\right]$-labeled species, the loss of a propene molecule with one $\mathrm{D}$ atom less than in the propyl group in the parent species is relatively pronounced; that is, $\mathrm{C}_{3} \mathrm{H}_{4} \mathrm{D}_{2}$ and $\mathrm{C}_{3} \mathrm{H}_{3} \mathrm{D}_{3}$ are expelled in a ratio of 33:67 from the metastable [M+ $\mathrm{D}^{+}$ions.

The introduction of two deuterium atoms at the $\alpha$-position of the 3- $n$-propoxypyridines results in the losses of $\mathrm{C}_{3} \mathrm{H}_{5} \mathrm{D}$ and $\mathrm{C}_{3} \mathrm{H}_{4} \mathrm{D}_{2}$ in an average ratio of 21:79 (Table 2). For the related $\left[\beta, \beta-\mathrm{D}_{2}\right]$-labeled ions (eq 3), loss of $\mathrm{C}_{3} \mathrm{H}_{5} \mathrm{D}$ is more pronounced than observed for the $\left[\alpha, \alpha-\mathrm{D}_{2}\right]$-labeled species.

$$
3-\left(\mathrm{C}_{5} \mathrm{H}_{4} \mathrm{~N}\right) \mathrm{O}\left(\mathrm{CH}_{2} \mathrm{CD}_{2} \mathrm{CH}_{3}\right) \stackrel{\left[\mathrm{D}^{+}\right]}{\longrightarrow}
$$

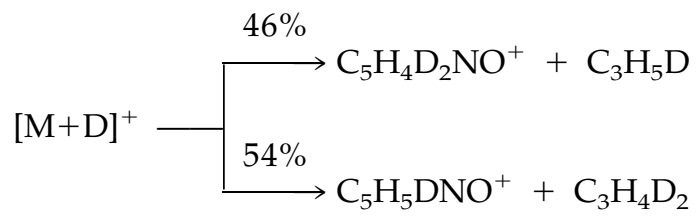

The results for the loss of propene from the metastable $[\mathrm{M}+\mathrm{D}]^{+}$ions of 4-n-propoxypyridine are dependent on the position of the labeling (Table 3). For example, deuterium incorporation at the $\alpha$-position results in a ratio of $22: 78$ between the losses of $\mathrm{C}_{3} \mathrm{H}_{3} \mathrm{D}$ and $\mathrm{C}_{3} \mathrm{H}_{4} \mathrm{D}_{2}$ from the metastable ions, whereas the ratio between these losses is 38:62 if two D atoms are present at the $\beta$-position (eq 4).

$$
4-\left(\mathrm{C}_{5} \mathrm{H}_{4} \mathrm{~N}\right) \mathrm{O}\left(\mathrm{CH}_{2} \mathrm{CD}_{2} \mathrm{CH}_{3}\right) \stackrel{\left[\mathrm{D}^{+}\right]}{\longrightarrow}
$$$$
[\mathrm{M}+\mathrm{D}]^{+} \stackrel{38 \%}{\stackrel{62 \%}{\longrightarrow}} \stackrel{\stackrel{6}{\longrightarrow}}{\stackrel{2}{\longrightarrow}} \mathrm{C}_{5} \mathrm{H}_{4} \mathrm{D}_{2} \mathrm{H}_{5} \mathrm{DNO}^{+}+\mathrm{C}_{3} \mathrm{H}_{5} \mathrm{D}
$$

\section{Isopropoxypyridines}

In order to investigate the influence of the structure of the propyl group on the process of propene loss, a series of $\left[\beta, \beta, \beta-\mathrm{D}_{3}\right]$-labeled isopropoxypyridines were studied. In contrast to the results for the $n$ propoxypyridines, the ratio between the losses of $\mathrm{C}_{3} \mathrm{H}_{4} \mathrm{D}_{2}$ and $\mathrm{C}_{3} \mathrm{H}_{3} \mathrm{D}_{3}$ from the metastable $[\mathrm{M}+\mathrm{D}]^{+}$ ions of the isopropoxypyridines appeared to be independent of the position of the substituent with re- 
Table 1. Relative extent (in \%) of the losses of $\mathrm{C}_{3} \mathrm{H}_{6}, \mathrm{C}_{3} \mathrm{H}_{5} \mathrm{D}, \mathrm{C}_{3} \mathrm{H}_{4} \mathrm{D}_{2}, \mathrm{C}_{3} \mathrm{H}_{3} \mathrm{D}_{3}$ and $\mathrm{C}_{3} \mathrm{D}_{6}$ from the metastable $[\mathrm{M}+\mathrm{D}]^{+}$ions of 2-n-propoxypyridine and deuterium labeled analogues

\begin{tabular}{|c|c|c|c|c|c|c|c|}
\hline \multirow[b]{2}{*}{ Compound M } & \multirow[b]{2}{*}{ Reactant ion } & \multirow[b]{2}{*}{$\mathrm{Cl}$ reagent } & \multicolumn{5}{|c|}{ Relative extent of the loss of ${ }^{a}$} \\
\hline & & & $\mathrm{C}_{3} \mathrm{H}_{6}$ & $\mathrm{C}_{3} \mathrm{H}_{5} \mathrm{D}$ & $\mathrm{C}_{3} \mathrm{H}_{4} \mathrm{D}_{2}$ & $\mathrm{C}_{3} \mathrm{H}_{3} \mathrm{D}_{3}$ & $\mathrm{C}_{3} \mathrm{D}_{6}$ \\
\hline \multirow{4}{*}{ 2- $\left(\mathrm{C}_{5} \mathrm{H}_{4} \mathrm{~N}\right)-\mathrm{OCH}_{2} \mathrm{CH}_{2} \mathrm{CH}_{3}{ }^{\mathrm{b}}$} & {$[\mathrm{M}+\mathrm{D}]^{+}$} & $\mathrm{CD}_{3} \mathrm{OD}$ & 100 & & & & \\
\hline & & $\mathrm{CD}_{3} \mathrm{CN}$ & 100 & & & & \\
\hline & & $\left(\mathrm{CD}_{3}\right)_{2} \mathrm{C}=\mathrm{O}$ & 100 & & & & \\
\hline & & Pyrrole- $D_{5}$ & 100 & & & & \\
\hline \multirow[t]{4}{*}{ 2- $\left(\mathrm{C}_{5} \mathrm{H}_{4} \mathrm{~N}\right)-\mathrm{OCD}_{2} \mathrm{CH}_{2} \mathrm{CH}_{3}{ }^{\mathrm{c}}$} & {$[\mathrm{M}+\mathrm{D}]^{+}$} & $\mathrm{CD}_{3} \mathrm{OD}$ & & 24 & 76 & & \\
\hline & & $\mathrm{CD}_{3} \mathrm{CN}$ & & 23 & 77 & & \\
\hline & & $\left(\mathrm{CD}_{3}\right)_{2} \mathrm{C}=\mathrm{O}$ & & 25 & 75 & & \\
\hline & & Pyrrole- $D_{5}$ & & 26 & 74 & & \\
\hline \multirow{4}{*}{ 2- $\left(\mathrm{C}_{5} \mathrm{H}_{4} \mathrm{~N}\right)-\mathrm{OCH}_{2} \mathrm{CD}_{2} \mathrm{CH}_{3}{ }^{\mathrm{c}}$} & {$[\mathrm{M}+\mathrm{D}]^{+}$} & $\mathrm{CD}_{3} \mathrm{OD}$ & & 24 & 76 & & \\
\hline & & $\mathrm{CD}_{3} \mathrm{CN}$ & & 25 & 75 & & \\
\hline & & $\left(\mathrm{CD}_{3}\right)_{2} \mathrm{C}=\mathrm{O}$ & & 24 & 76 & & \\
\hline & & Pyrrole- $D_{5}$ & & 23 & 77 & & \\
\hline \multirow[t]{4}{*}{ 2- $\left(\mathrm{C}_{5} \mathrm{H}_{4} \mathrm{~N}\right)-\mathrm{OCH}_{2} \mathrm{CH}_{2} \mathrm{CD}_{3}{ }^{\mathrm{c}}$} & {$[M+D]^{+}$} & $\mathrm{CD}_{3} \mathrm{OD}$ & & & 32 & 68 & \\
\hline & & $\mathrm{CD}_{3} \mathrm{CN}$ & & & 33 & 67 & \\
\hline & & $\left(\mathrm{CD}_{3}\right)_{2} \mathrm{C}=\mathrm{O}$ & & & 33 & 67 & \\
\hline & & Pyrrole- $D_{5}$ & & & 33 & 67 & \\
\hline \multirow[t]{4}{*}{ 2- $\left(\mathrm{C}_{5} \mathrm{H}_{4} \mathrm{~N}\right)-\mathrm{OCD}_{2} \mathrm{CD}_{2} \mathrm{CD}_{3}{ }^{\mathrm{d}}$} & {$[\mathrm{M}+\mathrm{D}]^{+}$} & $\mathrm{CD}_{3} \mathrm{OD}$ & & & & & 100 \\
\hline & & $\mathrm{CD}_{3} \mathrm{CN}$ & & & & & 100 \\
\hline & & $\left(\mathrm{CD}_{3}\right)_{2} \mathrm{C}=\mathrm{O}$ & & & & & 100 \\
\hline & & Pyrrole- $D_{5}$ & & & & & 100 \\
\hline
\end{tabular}

aThe ratios are considered to be accurate to within a few percent.

bpropene loss from the $[M+D]^{+}$ions yields only $\mathrm{C}_{5} \mathrm{H}_{5} \mathrm{DNO}^{+}(\mathrm{m} / \mathrm{z} 97)$ ions.

cPropene loss from the $[M+D]^{+}$ions yields $\mathrm{C}_{5} \mathrm{H}_{5} \mathrm{DNO}^{+}(\mathrm{m} / \mathrm{z} 97)$ and $\mathrm{C}_{5} \mathrm{H}_{5} \mathrm{D}_{2} \mathrm{NO}^{+}(\mathrm{m} / \mathrm{z} 98)$ ions.

deropene loss from the $[M+D]^{+}$ions yields only $\mathrm{C}_{5} \mathrm{H}_{4} \mathrm{D}_{2} \mathrm{NO}^{+}(\mathrm{m} / \mathrm{z} 98)$ ions.

spect to the nitrogen atom (see Table 4 and eq 5). In addition, deuterium incorporation at the $\alpha$-position of the isopropoxy group revealed that the $\alpha$-hydrogen atom is not involved in the loss of propene.

Table 2. Relative extent (in \%) of the losses of $\mathrm{C}_{3} \mathrm{H}_{6}, \mathrm{C}_{3} \mathrm{H}_{5} \mathrm{D}, \mathrm{C}_{3} \mathrm{H}_{4} \mathrm{D}_{2}, \mathrm{C}_{3} \mathrm{H}_{3} \mathrm{D}_{3}$ and $\mathrm{C}_{3} \mathrm{D}_{6}$ from the metastable $[\mathrm{M}+\mathrm{D}]^{+}$ions of 3-n-propoxypyridine and deuterium labeled analogues

\begin{tabular}{|c|c|c|c|c|c|c|c|}
\hline \multirow[b]{2}{*}{ Compound M } & \multirow[b]{2}{*}{ Reactant ion } & \multirow[b]{2}{*}{$\mathrm{Cl}$ reagent } & \multicolumn{5}{|c|}{ Relative extent of the loss of ${ }^{a}$} \\
\hline & & & $\mathrm{C}_{3} \mathrm{H}_{6}$ & $\mathrm{C}_{3} \mathrm{H}_{5} \mathrm{D}$ & $\mathrm{C}_{3} \mathrm{H}_{4} \mathrm{D}_{2}$ & $\mathrm{C}_{3} \mathrm{H}_{3} \mathrm{D}_{3}$ & $\mathrm{C}_{3} \mathrm{D}_{6}$ \\
\hline \multirow[t]{4}{*}{ 3- $\left(\mathrm{C}_{5} \mathrm{H}_{4} \mathrm{~N}\right)-\mathrm{OCH}_{2} \mathrm{CH}_{2} \mathrm{CH}_{3}{ }^{\mathrm{b}}$} & {$[\mathrm{M}+\mathrm{D}]^{+}$} & $\mathrm{CD}_{3} \mathrm{OD}$ & 100 & 0 & & & \\
\hline & & $\mathrm{CD}_{3} \mathrm{CN}$ & 100 & 0 & & & \\
\hline & & $\left(\mathrm{CD}_{3}\right)_{2} \mathrm{C}=\mathrm{O}$ & 100 & 0 & & & \\
\hline & & Pyrrole- $D_{5}$ & 100 & 0 & & & \\
\hline \multirow[t]{4}{*}{ 3- $\left(\mathrm{C}_{5} \mathrm{H}_{4} \mathrm{~N}\right)-\mathrm{OCD}_{2} \mathrm{CH}_{2} \mathrm{CH}_{3}{ }^{\mathrm{c}}$} & {$[\mathrm{M}+\mathrm{D}]^{+}$} & $\mathrm{CD}_{3} \mathrm{OD}$ & & 21 & 79 & & \\
\hline & & $\mathrm{CD}_{3} \mathrm{CN}$ & & 20 & 80 & & \\
\hline & & $\left(\mathrm{CD}_{3}\right)_{2} \mathrm{C}=\mathrm{O}$ & & 21 & 79 & & \\
\hline & & Pyrrole- $D_{5}$ & & 21 & 79 & & \\
\hline \multirow{4}{*}{ 3- $\left(\mathrm{C}_{5} \mathrm{H}_{4} \mathrm{~N}\right)-\mathrm{OCH}_{2} \mathrm{CD}_{2} \mathrm{CH}_{3}{ }^{\mathrm{c}}$} & {$[\mathrm{M}+\mathrm{D}]^{+}$} & $\mathrm{CD}_{3} \mathrm{OD}$ & & 46 & 54 & & \\
\hline & & $\mathrm{CD}_{3} \mathrm{CN}$ & & 46 & 54 & & \\
\hline & & $\left(\mathrm{CD}_{3}\right)_{2} \mathrm{C}=\mathrm{O}$ & & 48 & 52 & & \\
\hline & & Pyrrole- $D_{5}$ & & 46 & 54 & & \\
\hline \multirow[t]{4}{*}{$3-\left(\mathrm{C}_{5} \mathrm{H}_{4} \mathrm{~N}\right)-\mathrm{OCH}_{2} \mathrm{CH}_{2} \mathrm{CD}_{3}^{\mathrm{c}, \mathrm{d}}$} & {$[\mathrm{M}+\mathrm{D}]^{+}$} & $\mathrm{CD}_{3} \mathrm{OD}$ & & & 22 & 78 & \\
\hline & & $\mathrm{CD}_{3} \mathrm{CN}$ & & & 18 & 82 & \\
\hline & & $\left(\mathrm{CD}_{3}\right)_{2} \mathrm{C}=\mathrm{O}$ & & & 14 & 86 & \\
\hline & & Pyrrole- $\mathrm{D}_{5}$ & & & 22 & 78 & \\
\hline \multirow[t]{3}{*}{ 3- $\left(\mathrm{C}_{5} \mathrm{H}_{4} \mathrm{~N}\right)-\mathrm{OCD}_{2} \mathrm{CD}_{2} \mathrm{CD}_{3}{ }^{\mathrm{e}}$} & {$[\mathrm{M}+\mathrm{D}]^{+}$} & $\mathrm{CD}_{3} \mathrm{OD}$ & & & & & 100 \\
\hline & & $\left(\mathrm{CD}_{3}\right)_{2} \mathrm{C}=\mathrm{O}$ & & & & & 100 \\
\hline & & Pyrrole- $D_{5}$ & & & & & 100 \\
\hline
\end{tabular}

aThe ratios are considered to be accurate to within a few percent.

${ }^{b}$ Propene loss from the $[M+D]^{+}$ions yields only $\mathrm{C}_{5} \mathrm{H}_{5} \mathrm{DNO}^{+}(\mathrm{m} / \mathrm{z} 97)$ ions.

cPropene loss from the $[M+D]^{+}$ions yields $\mathrm{C}_{5} \mathrm{H}_{5} \mathrm{DNO}^{+}(\mathrm{m} / \mathrm{z} 97)$ and $\mathrm{C}_{5} \mathrm{H}_{4} \mathrm{D}_{2} \mathrm{NO}^{+}(\mathrm{m} / \mathrm{z} 98)$ ions.

${ }^{\mathrm{d}}$ The results for the $\left[\gamma, \gamma, \gamma-\mathrm{D}_{3}\right]$ labeled ions as based upon peak areas are considered to be less accurate than the other values in the table due to enhanced overlap of the metastable peaks.

epropene loss from the $[M+D]^{+}$ions yields only $\mathrm{C}_{5} \mathrm{H}_{4} \mathrm{D}_{2} \mathrm{NO}^{+}(\mathrm{m} / \mathrm{z} 98)$ ions. 
Table 3. Relative extent (in \%) of the losses of $\mathrm{C}_{3} \mathrm{H}_{6}, \mathrm{C}_{3} \mathrm{H}_{5} \mathrm{D}, \mathrm{C}_{3} \mathrm{H}_{4} \mathrm{D}_{2}, \mathrm{C}_{3} \mathrm{H}_{3} \mathrm{D}_{3}$ and $\mathrm{C}_{3} \mathrm{D}_{6}$ from the metastable $[\mathrm{M}+\mathrm{D}]^{+}$ions of 4-n-propoxypyridine and deuterium labeled analogues

\begin{tabular}{|c|c|c|c|c|c|c|c|}
\hline \multirow[b]{2}{*}{ Compound M } & \multirow[b]{2}{*}{ Reactant ion } & \multirow[b]{2}{*}{$\mathrm{Cl}$ reagent } & \multicolumn{5}{|c|}{ Relative extent of the loss of ${ }^{a}$} \\
\hline & & & $\mathrm{C}_{3} \mathrm{H}_{6}$ & $\mathrm{C}_{3} \mathrm{H}_{5} \mathrm{D}$ & $\mathrm{C}_{3} \mathrm{H}_{4} \mathrm{D}_{2}$ & $\mathrm{C}_{3} \mathrm{H}_{3} \mathrm{D}_{3}$ & $\mathrm{C}_{3} \mathrm{D}_{6}$ \\
\hline \multirow{4}{*}{ 4- $\left(\mathrm{C}_{5} \mathrm{H}_{4} \mathrm{~N}\right)-\mathrm{OCH}_{2} \mathrm{CH}_{2} \mathrm{CH}_{3}^{\mathrm{b}}$} & {$[\mathrm{M}+\mathrm{D}]^{+}$} & $\mathrm{CD}_{3} \mathrm{OD}$ & 100 & 0 & & & \\
\hline & & $\mathrm{CD}_{3} \mathrm{CN}$ & 100 & 0 & & & \\
\hline & & $\left(\mathrm{CD}_{3}\right)_{2} \mathrm{C}=\mathrm{O}$ & 100 & 0 & & & \\
\hline & & Pyrrole- $\mathrm{D}_{5}$ & 100 & 0 & & & \\
\hline \multirow[t]{4}{*}{ 4- $\left(\mathrm{C}_{5} \mathrm{H}_{4} \mathrm{~N}\right)-\mathrm{OCD}_{2} \mathrm{CH}_{2} \mathrm{CH}_{3}{ }^{\mathrm{c}}$} & {$[\mathrm{M}+\mathrm{D}]^{+}$} & $\mathrm{CD}_{3} \mathrm{OD}$ & & 21 & 79 & & \\
\hline & & $\mathrm{CD}_{3} \mathrm{CN}$ & & 21 & 79 & & \\
\hline & & $\left(\mathrm{CD}_{3}\right)_{2} \mathrm{C}=\mathrm{O}$ & & 23 & 77 & & \\
\hline & & Pyrrole- $D_{5}$ & & 22 & 78 & & \\
\hline \multirow{4}{*}{ 4- $\left(\mathrm{C}_{5} \mathrm{H}_{4} \mathrm{~N}\right)-\mathrm{OCH}_{2} \mathrm{CD}_{2} \mathrm{CH}_{3}{ }^{\mathrm{c}}$} & {$[\mathrm{M}+\mathrm{D}]^{+}$} & $\mathrm{CD}_{3} \mathrm{OD}$ & & 38 & 62 & & \\
\hline & & $\mathrm{CD}_{3} \mathrm{CN}$ & & 39 & 61 & & \\
\hline & & $\left(\mathrm{CD}_{3}\right)_{2} \mathrm{C}=\mathrm{O}$ & & 37 & 63 & & \\
\hline & & Pyrrole- $\mathrm{D}_{5}$ & & 34 & 66 & & \\
\hline \multirow[t]{4}{*}{ 4- $\left(\mathrm{C}_{5} \mathrm{H}_{4} \mathrm{~N}\right)-\mathrm{OCH}_{2} \mathrm{CH}_{2} \mathrm{CD}_{3}{ }^{\mathrm{c}}$} & {$[\mathrm{M}+\mathrm{D}]^{+}$} & $\mathrm{CD}_{3} \mathrm{OD}$ & & & 26 & 74 & \\
\hline & & $\mathrm{CD}_{3} \mathrm{CN}$ & & & 27 & 73 & \\
\hline & & $\left(\mathrm{CD}_{3}\right)_{2} \mathrm{C}=\mathrm{O}$ & & & 29 & 71 & \\
\hline & & Pyrrole- $D_{5}$ & & & 28 & 72 & \\
\hline \multirow[t]{4}{*}{ 4- $\left(\mathrm{C}_{5} \mathrm{H}_{4} \mathrm{~N}\right)-\mathrm{OCD}_{2} \mathrm{CD}_{2} \mathrm{CD}_{3}{ }^{\mathrm{d}}$} & {$[\mathrm{M}+\mathrm{D}]^{+}$} & $\mathrm{CD}_{3} \mathrm{OD}$ & & & & & 100 \\
\hline & & $\mathrm{CD}_{3} \mathrm{CN}$ & & & & & 100 \\
\hline & & $\left(\mathrm{CD}_{3}\right)_{2} \mathrm{C}=\mathrm{O}$ & & & & & 100 \\
\hline & & Pyrrole- $D_{5}$ & & & & & 100 \\
\hline
\end{tabular}

The ratios are considered accurate to within a few percent.

bPropene loss from the $[\mathrm{M}+\mathrm{D}]^{+}$ions yields only $\mathrm{C}_{5} \mathrm{H}_{5} \mathrm{DNO}^{+}(\mathrm{m} / \mathrm{z} 97)$ ions.

cPropene loss from the $[M+D]^{+}$ions yields $\mathrm{C}_{5} \mathrm{H}_{5} \mathrm{DNO}^{+}(\mathrm{m} / \mathrm{z} 97)$ and $\mathrm{C}_{5} \mathrm{H}_{4} \mathrm{D}_{2} \mathrm{NO}^{+}(\mathrm{m} / \mathrm{z} 98)$ ions.

deropene loss from the $[\mathrm{M}+\mathrm{D}]^{+}$ions yields only $\mathrm{C}_{5} \mathrm{H}_{4} \mathrm{D}_{2} \mathrm{NO}^{+}(\mathrm{m} / \mathrm{z} 98)$ ions.

$[\mathrm{M}+\mathrm{D}]^{+} \stackrel{34 \%}{\stackrel{\mathrm{66 \%}}{\longrightarrow}} \mathrm{C}_{5} \mathrm{H}_{4} \mathrm{D}_{2} \mathrm{NO}^{+}+\mathrm{C}_{3} \mathrm{H}_{4} \mathrm{D}_{2}$

For the isopropoxypyridines, the results for propene loss from the metastable ions are independent of the nature of the CI gas. In other words the initial transfer of a deuteron from the Brønsted acid of the CI gas has no influence on the origin of the $\mathrm{H}$ or D atoms incorporated in the ionic product of propene loss from the $[\mathrm{M}+\mathrm{D}]^{+}$ions. Similar results were obtained for the n-propoxypyridines (see Tables $1-3$ ). In addition, the same ratio between the losses of $\mathrm{C}_{3} \mathrm{H}_{5} \mathrm{D}$ and $\mathrm{C}_{3} \mathrm{H}_{4} \mathrm{D}_{2}$ from the metastable $[\mathrm{M}+\mathrm{D}]^{+}$ions of $\left[\beta, \beta-\mathrm{D}_{2}\right]-3-n-$ propoxypyridines is obtained for a total pressure of $5 \times$ $10^{-6} \mathrm{mbar}$ and at a pressure of $1 \times 10^{-4} \mathrm{mbar}$ in the ion source (see also Experimental).

Table 4. Relative extent (in \%) of the losses of $\mathrm{C}_{3} \mathrm{H}_{6}, \mathrm{C}_{3} \mathrm{H}_{5} \mathrm{D}, \mathrm{C}_{3} \mathrm{H}_{4} \mathrm{D}_{2}, \mathrm{C}_{3} \mathrm{H}_{3} \mathrm{D}_{3}$ and $\mathrm{C}_{3} \mathrm{D}_{6}$ from the metastable $[\mathrm{M}+\mathrm{D}]^{+}$ions of isopropoxypyridine and deuterium labeled analogues

\begin{tabular}{|c|c|c|c|c|c|c|}
\hline \multirow[b]{2}{*}{ Compound M } & \multirow{2}{*}{$\begin{array}{l}\text { Reactant } \\
\text { ion }\end{array}$} & \multicolumn{5}{|c|}{ Relative extent of the loss of ${ }^{a}$} \\
\hline & & $\mathrm{C}_{3} \mathrm{H}_{6}$ & $\mathrm{C}_{3} \mathrm{H}_{5} \mathrm{D}$ & $\mathrm{C}_{3} \mathrm{H}_{4} \mathrm{D}_{2}$ & $\mathrm{C}_{3} \mathrm{H}_{3} \mathrm{D}_{3}$ & $\mathrm{C}_{3} \mathrm{D}_{6}$ \\
\hline 2-( $\left(\mathrm{C}_{5} \mathrm{H}_{4} \mathrm{~N}\right)-\mathrm{OCH}\left(\mathrm{CH}_{3}\right)_{2}^{\mathrm{b}}$ & {$[M+D]^{+}$} & 100 & & & & \\
\hline $2-\left(\mathrm{C}_{5} \mathrm{H}_{4} \mathrm{~N}\right)-\mathrm{OCD}\left(\mathrm{CD}_{3}\right)_{2}^{\mathrm{c}}$ & {$[\mathrm{M}+\mathrm{D}]^{+}$} & & & & & 100 \\
\hline 2- $\left(\mathrm{C}_{5} \mathrm{H}_{4} \mathrm{~N}\right)-\mathrm{OCD}\left(\mathrm{CH}_{3}\right)_{2}^{\mathrm{b}}$ & {$[\mathrm{M}+\mathrm{D}]^{+}$} & & 100 & & & \\
\hline 2- $\left(\mathrm{C}_{5} \mathrm{H}_{4} \mathrm{~N}\right)-\mathrm{OCH}\left(\mathrm{CD}_{3}\right)\left(\mathrm{CH}_{3}\right)^{\mathrm{d}}$ & {$[\mathrm{M}+\mathrm{D}]^{+}$} & & & 31 & 69 & \\
\hline 3- $\left(\mathrm{C}_{5} \mathrm{H}_{4} \mathrm{~N}\right)-\mathrm{OCH}\left(\mathrm{CH}_{3}\right)_{2}^{\mathrm{b}}$ & {$[\mathrm{M}+\mathrm{D}]^{+}$} & 100 & & & & \\
\hline 3- $\left(\mathrm{C}_{5} \mathrm{H}_{4} \mathrm{~N}\right)-\mathrm{OCD}\left(\mathrm{CD}_{3}\right)_{2}^{\mathrm{b}}$ & {$[\mathrm{M}+\mathrm{D}]^{+}$} & & & & & 100 \\
\hline 3- $\left(\mathrm{C}_{5} \mathrm{H}_{4} \mathrm{~N}\right)-\mathrm{OCD}\left(\mathrm{CH}_{3}\right)_{2}^{\mathrm{b}}$ & {$[\mathrm{M}+\mathrm{D}]^{+}$} & & 100 & & & \\
\hline 3- $\left(\mathrm{C}_{5} \mathrm{H}_{4} \mathrm{~N}\right)-\mathrm{OCH}\left(\mathrm{CD}_{3}\right)\left(\mathrm{CH}_{3}\right)^{\mathrm{d}}$ & {$[\mathrm{M}+\mathrm{D}]^{+}$} & & & 34 & 66 & \\
\hline 4- $\left(\mathrm{C}_{5} \mathrm{H}_{4} \mathrm{~N}\right)-\mathrm{OCH}\left(\mathrm{CH}_{3}\right)_{2}^{\mathrm{b}}$ & {$[\mathrm{M}+\mathrm{D}]^{+}$} & 100 & & & & \\
\hline 4- $\left(\mathrm{C}_{5} \mathrm{H}_{4} \mathrm{~N}\right)-\mathrm{OCD}\left(\mathrm{CD}_{3}\right)_{2}{ }^{\mathrm{b}}$ & {$[\mathrm{M}+\mathrm{D}]^{+}$} & & & & & 100 \\
\hline 4- $\left(\mathrm{C}_{5} \mathrm{H}_{4} \mathrm{~N}\right)-\mathrm{OCD}\left(\mathrm{CH}_{3}\right)_{2}^{\mathrm{b}}$ & {$[\mathrm{M}+\mathrm{D}]^{+}$} & & 100 & & & \\
\hline 4- $\left(\mathrm{C}_{5} \mathrm{H}_{4} \mathrm{~N}\right)-\mathrm{OCH}\left(\mathrm{CD}_{3}\right)\left(\mathrm{CH}_{3}\right)^{\mathrm{d}}$ & {$[\mathrm{M}+\mathrm{D}]^{+}$} & & & 34 & 66 & \\
\hline
\end{tabular}

aThe relative abundances are independent of the $\mathrm{Cl}$ gas used (see Results section) and accurate to within a few percent.

bPropene loss from the $[M+D]^{+}$ions yields only $\mathrm{C}_{5} \mathrm{H}_{5} \mathrm{DNO}^{+}(\mathrm{m} / \mathrm{z}$ 97) ions.

cPropene loss from the $[M+D]^{+}$ions yields only $\mathrm{C}_{5} \mathrm{H}_{4} \mathrm{D}_{2} \mathrm{NO}^{+}(\mathrm{m} / z \mathrm{~g})$ ions.

dPropene loss from the $[\mathrm{M}+\mathrm{D}]^{+}$ions yields $\mathrm{C}_{5} \mathrm{H}_{5} \mathrm{DNO}^{+}(\mathrm{m} / \mathrm{z} 97)$ and $\mathrm{C}_{5} \mathrm{H}_{4} \mathrm{D}_{2} \mathrm{NO}^{+}(\mathrm{m} / \mathrm{z} 98)$ ions. 


\section{Collision-Induced Dissociation}

A series of CID experiments [33] were performed with the $[\mathrm{M}+\mathrm{D}]^{+}$ions of the propoxypyridines (see Experimental). The collisionally induced loss of propene from the $[\mathrm{M}+\mathrm{D}]^{+}$ions of the unlabeled 2-, 3-, and 4-npropoxypyridines involves only the expulsion of $\mathrm{C}_{3} \mathrm{H}_{6}$. For the $[\mathrm{M}+\mathrm{D}]^{+}$ions of the $\left[\alpha, \alpha-\mathrm{D}_{2}\right]-$ or $\left[\beta, \beta-\mathrm{D}_{2}\right]-$ labeled 2-, 3-, and 4-n-propoxypyridines, the ratio between the losses of $\mathrm{C}_{3} \mathrm{H}_{5} \mathrm{D}$ and $\mathrm{C}_{3} \mathrm{H}_{4} \mathrm{D}_{2}$ is essentially the same in the CID experiments as observed for the metastable ions. Notably, the ratio between the losses of $\mathrm{C}_{3} \mathrm{H}_{5} \mathrm{D}$ and $\mathrm{C}_{3} \mathrm{H}_{4} \mathrm{D}_{2}$ in the CID experiments is $75: 25$ for the $[\mathrm{M}+\mathrm{D}]^{+}$ions of the $\left[\beta, \beta-\mathrm{D}_{2}\right]-2-n$-propoxypyridine and about $40: 60$ for the $\left[\beta, \beta-\mathrm{D}_{2}\right]-3-n$-propoxypyridine (see also Tables 1 and 2). Similar results are obtained for the competing losses of $\mathrm{C}_{3} \mathrm{H}_{4} \mathrm{D}_{2}$ and $\mathrm{C}_{3} \mathrm{H}_{3} \mathrm{D}_{3}$ from the $[\mathrm{M}+\mathrm{D}]^{+}$ions of the $\left[\gamma, \gamma, \gamma-\mathrm{D}_{3}\right]$-labeled $n$-propoxypyridines. It should be mentioned, however, that propene loss from the metastable $[\mathrm{M}+\mathrm{D}]^{+}$ions contribute to the intensities of the peaks in the CID spectra and-a priori-it is not possible to separate the collisionally induced processes from the spontaneous reactions of the ions. The relative peak intensities in the CID spectra, therefore, may not necessarily provide a unambiguous measure of the relative extent of the collisionally induced losses of $\mathrm{C}_{3} \mathrm{H}_{5} \mathrm{D}$ and $\mathrm{C}_{3} \mathrm{H}_{4} \mathrm{D}_{2}$ from the $[\mathrm{M}+\mathrm{D}]^{+}$ ions of, for example, the $\left[\beta, \beta-\mathrm{D}_{2}\right]-3-n$-propoxypyridine.

The structures of the product ions of propene loss were also examined by high kinetic energy CID experiments. These experiments were performed with the product ions of propene loss as formed to a minor extent in the ion-source reactions of the $[\mathrm{M}+\mathrm{D}]^{+}$ions of the unlabeled propoxypyridines. The spectrum obtained for the $\mathrm{C}_{5} \mathrm{H}_{5} \mathrm{DNO}^{+}$ions generated by $\mathrm{C}_{3} \mathrm{H}_{6}$ loss from the $[\mathrm{M}+\mathrm{D}]^{+}$ion of 3-n-propoxypyridine is shown in Figure 2a and appears to very similar to the CID spectrum of the $[\mathrm{M}+\mathrm{D}]^{+}$ion of 3-hydroxypyridine (see Figure 2b). Comparable results were obtained for the other product ions of propene loss from the ionized propoxypyridines and the related protonated hydroxypyridines.

\section{Discussion}

The dissociation reactions of ions in the gas phase often involve the intermediate formation of ion-neutral complexes held together by electrostatic interactions and/or hydrogen bonds [21, 34-40]. The involvement of ionneutral complexes is generally manifested in the energetics of the processes and the loss of the positional identity of, for example, hydrogen atoms prior to dissociation. For example, the metastable ions formed by proton transfer to $n$-propyl benzene under CI conditions are reported to isomerize irreversibly to protonated isopropylbenzene prior to propene loss [36, 41, 42]. The suggested pathway involves cleavage of the bond to the $n$-propyl group concomitant with a 1,2-hydride shift in the incipient carbenium ion. The ion-neutral
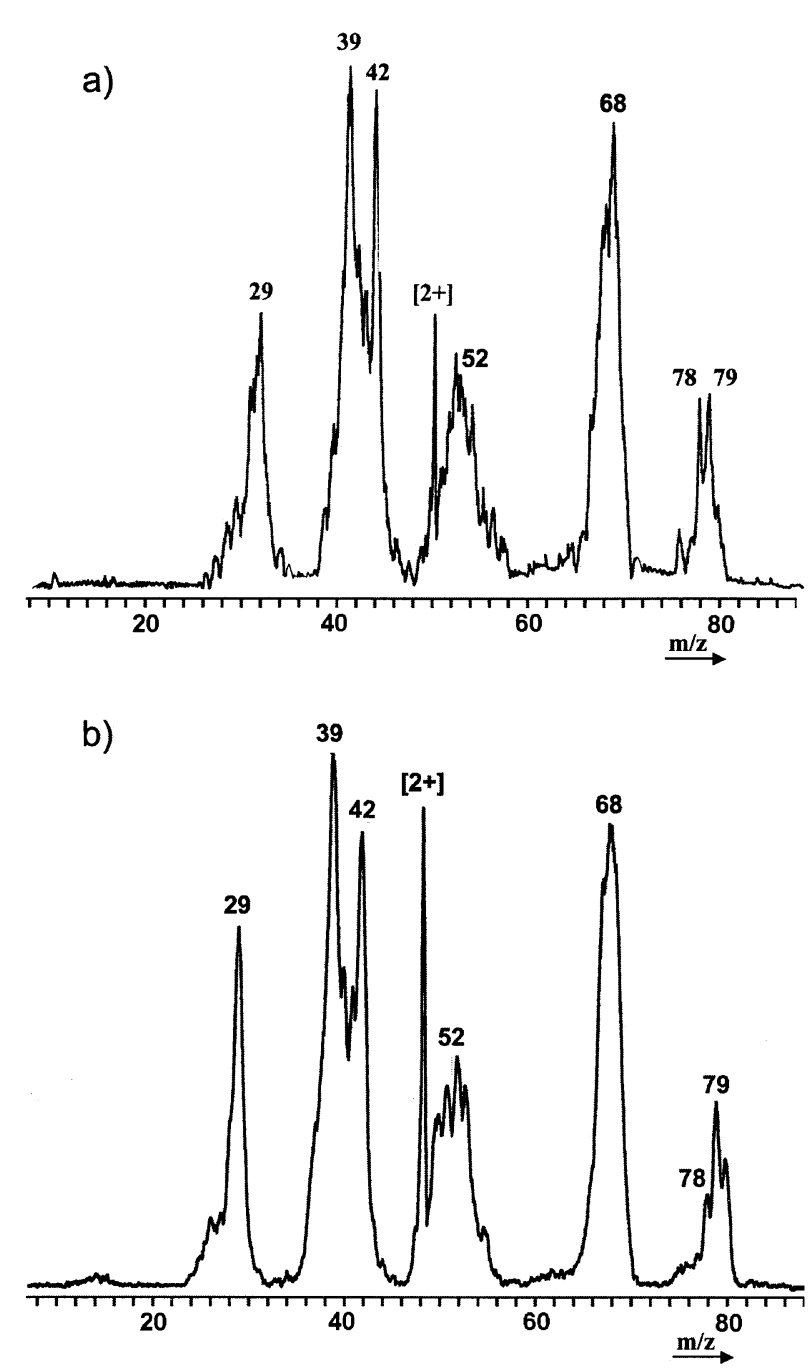

Figure 2. (a) The Collision-induced Dissociation mass spectrum of the $\mathrm{C}_{5} \mathrm{H}_{5} \mathrm{DNO}^{+}$ion formed by $\mathrm{C}_{3} \mathrm{H}_{6}$ loss from the metastable $[\mathrm{M}+\mathrm{D}]^{+}$ions of 3-n-propoxypyridine. (b) The CID spectrum of the $[\mathrm{M}+\mathrm{D}]^{+}$ion of 3-hydroxypyridine as generated with $\mathrm{CD}_{3} \mathrm{COCD}_{3}$ as the $\mathrm{CI}$ reagent gas.

complex of a benzene molecule and a secondary propyl carbenium ion reacts reversibly by proton transfer thus leading to partial incorporation of the hydrogen atom from the CI reagent into the propene molecule expelled from the metastable ions. Comparable studies have been reported for the loss of propene from the metastable protonated aryl $n$-propyl ethers [16, 17, 20]. For these compounds, protonation under CI conditions may occur either on the aromatic ring or on the oxygen atom of the ether function, thus leading to isomeric ions that can expel propene by different pathways. In previous studies it was concluded that only the transfer of a deuteron to the oxygen atom results in interchange between the propyl hydrogen atoms and the deuterium atom of the labeled CI reagent $[16,17]$. The extent of incorporation of the deuterium atom from the CI reagent into the propene molecule was observed to depend on the presence and position of a methyl group or a fluorine atom on the ring. In particular, the ratio 

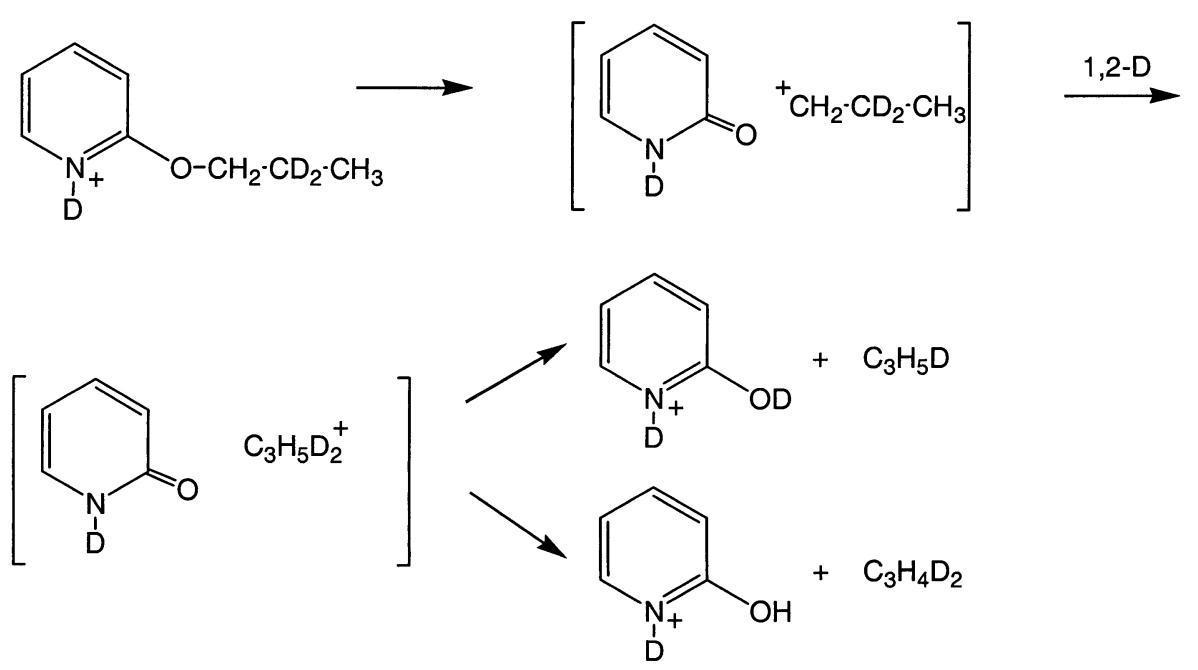

Scheme 1. Proposed mechanism of propene loss from the metastable $[\mathrm{M}+\mathrm{D}]^{+}$ions of 2- $n$ propoxypyridine with intermediate formation of ion-neutral complexes and complete loss of the positional identity of the hydrogen/deuterium atoms of the propyl carbenium ion.

between the losses of $\mathrm{C}_{3} \mathrm{H}_{5} \mathrm{D}$ and $\mathrm{C}_{3} \mathrm{H}_{6}$ from the metastable $[\mathrm{M}+\mathrm{D}]^{+}$ions of $n$-propyl-3-methylphenyl ether was reported to be 13:87, whereas this ratio becomes $27: 73$ if the methyl group is situated at the 4-position of the ring [16]. In terms of the initial protonation site, the presence of a methyl at the 4-position may disfavor proton transfer to the ring [43] and-as a resultprotonation at the oxygen atom becomes relatively important under CI conditions.

For the present series of aromatic ethers, the results reveal that the loss of propene from $[\mathrm{M}+\mathrm{D}]^{+}$ions occurs without interchange between the deuterium atom from the $\mathrm{CI}$ reagents and the hydrogen atoms of the propyl group. Even though the site-specific proton affinities of the pyridine ring of the ethers are unknown, deuteron transfer to the nitrogen atom is expected to be associated with strong thermodynamic driving force. The existence of a strong thermodynamic preference for transfer to the nitrogen atom is substantiated by the calculated proton affinity of $946 \mathrm{~kJ} \mathrm{~mol}^{-1}$ for this site in 3-hydroxypyridine, whereas the value for the oxygen atom is suggested to be much lower $\left(726 \mathrm{~kJ} \mathrm{~mol}^{-1}\right)$ [44, 45]. For the propoxypyridines, it may be anticipated that the proton affinity of the oxygen atom may be somewhat higher as compared to the same position in the hydroxypyridines due to the stabilization of the positive charge by the alkyl group in the oxygen protonated species. This could imply that that some endothermic deuteron transfer to the oxygen atom of the propoxypyridines may occur in the experiments with $\mathrm{CD}_{3} \mathrm{OD}\left(\mathrm{PA}=754 \mathrm{~kJ} \mathrm{~mol}^{-1}\right)$ and $\mathrm{CD}_{3} \mathrm{CN}(\mathrm{PA}=779 \mathrm{~kJ}$ $\left.\mathrm{mol}^{-1}\right)$, whereas the reagents, $\left(\mathrm{CD}_{3}\right)_{2} \mathrm{CO}$ and pyrrole$\mathrm{D}_{5}$, may be too strong bases (PA $=812$ and $875 \mathrm{~kJ}$ $\mathrm{mol}^{-1}$, respectively) [25] to allow the occurrence of deuteron transfer to this site in the ethers under the present CI conditions. Notwithstanding that it cannot be excluded that some deuteron transfer occurs to other sites than the nitrogen atom in the present experiments, the combined results indicate that loss of propene involves predominantly $[\mathrm{M}+\mathrm{D}]^{+}$ions formed by deuteronation at the nitrogen atom.

In spite of the conclusion that the results are in line with formation of nitrogen deuteronated species, the results suggest the occurrence of propene loss by a number of pathways; that is, propene loss from the metastable $[\mathrm{M}+\mathrm{D}]^{+}$ions of the propoxypyridines can involve: (1) Ion-neutral complex formation and loss of the positional identity of all hydrogen atoms of the propyl carbenium ion part of the complex, (2) ionneutral complex formation by cleavage of the ether bond associated with an irreversible 1,2-hydride shift in the carbenium ion if a $n$-propyl group is present in the parent compound or with no loss of positional identity of the hydrogen atoms of the carbenium ion if the ether contains an isopropyl group, (3) a 1,5-hydride shift from the $\beta$-position of the propyl group to the pyridine ring concomitant with dissociation, and (4) a 1,2-elimination type process.

The formation of ion-neutral complexes is suggested to be the predominant or even the exclusive pathway involved in the loss of propene from the $[\mathrm{M}+\mathrm{D}]^{+}$ions of the 2- $n$-propoxypyridine. For this particular species, the experimental ratio between the losses of $\mathrm{C}_{3} \mathrm{H}_{5} \mathrm{D}$ and $\mathrm{C}_{3} \mathrm{H}_{4} \mathrm{D}_{2}$ (24:76) from the $\left[\mathrm{D}_{2}\right]$-labeled propoxypyridines is slightly different from the ratio (29:71) calculated on the basis of formation of an ion-neutral complex with a propyl carbenium that may react by reversible 1,2hydride and deuteride shifts prior to proton or deuteron transfer (Scheme 1). This is further confirmed by the ratios of the loss of propene from the $\left[\gamma, \gamma, \gamma-\mathrm{D}_{3}\right]-2-$ n-propoxypyridines, which expel $\mathrm{C}_{3} \mathrm{H}_{4} \mathrm{D}_{2}$ and $\mathrm{C}_{3} \mathrm{H}_{3} \mathrm{D}_{3}$ in a ratio (33:67) that is also different from the statistical value (43:57). This statistical analysis is based, however, upon a neglect of isotope effects on the ensuing acidbase reaction between the partners of the complex. Possibly, the initial cleavage of the bond between the 


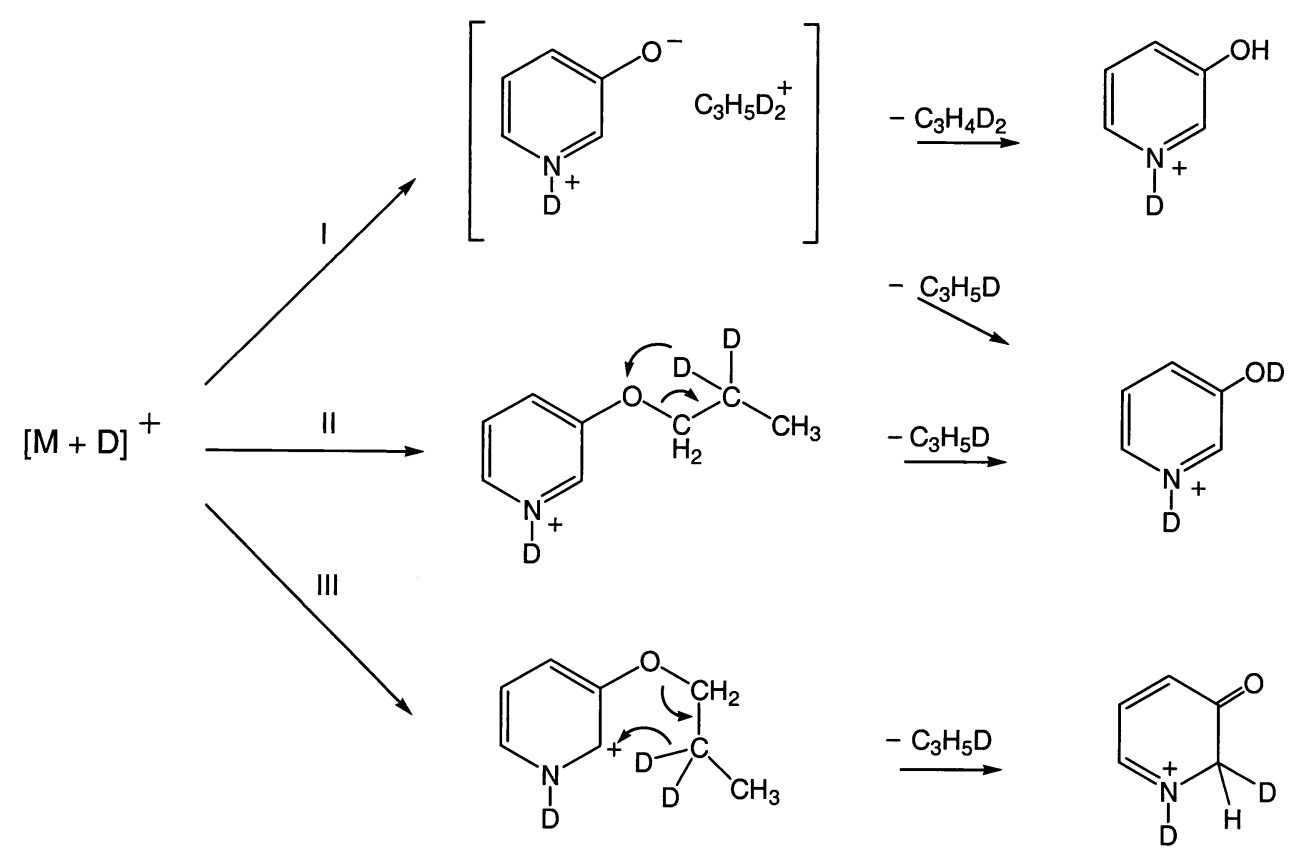

Scheme 2. Proposed mechanisms of propene loss from the metastable $[\mathrm{M}+\mathrm{D}]^{+}$ions of 3-npropoxypyridine. The first pathway (I) involves intermediate formation of ion-neutral complexes, the second pathway (II) is a 1,2-elimination type process and the third reaction (III) involves a 1,5-H shift.

oxygen atom and the $\alpha$-carbon atom of the propyl group is followed by a proton/deuteron transfer step with a small but discernible isotope effect (vide infra).

Even though the precise structure of the $\mathrm{C}_{5} \mathrm{H}_{4} \mathrm{NDO}$ molecule in the complexes shown in Scheme $\mathbf{1}$ is uncertain, it may be anticipated that cleavage of the ether bond leads to 2-pyridone. Upon the assumption that 2-pyridone is generated, proton transfer from the propyl carbenium ion to the oxygen atom is estimated to be exothermic with $\sim 180 \mathrm{~kJ} \mathrm{~mol}^{-1}$ as based on the experimental proton affinity of propene $(\mathrm{PA}=751 \mathrm{~kJ}$ $\mathrm{mol}^{-1}$ ) [25] and the calculated value of the oxygen atom in 2-pyridone $\left(933 \mathrm{~kJ} \mathrm{~mol}^{-1}\right)$ [24]. A large difference in proton affinity between propene and the 2-pyridone molecule within the ion-neutral complex shown in Scheme 1 will cause proton transfer to be essentially irreversible in line with the absence of incorporation of the deuterium atom from the CI reagent into the propene molecules.

The loss of propene from the metastable $[\mathrm{M}+\mathrm{D}]^{+}$ ions of the 3-n-propoxypyridine is likely to involve one of the other pathways in addition to the formation of ion-neutral complexes as indicated by the different experimental ratios between the losses of $\mathrm{C}_{3} \mathrm{H}_{5} \mathrm{D}$ and $\mathrm{C}_{3} \mathrm{H}_{4} \mathrm{D}_{2}$ from the $\left[\alpha, \alpha-\mathrm{D}_{2}\right]$ - and the $\left[\beta, \beta-\mathrm{D}_{2}\right]$-labeled species (Table 2). For the $\left[\alpha, \alpha-\mathrm{D}_{2}\right]$-labeled ions, the average ratio of 21:79 suggests that transfer of a deuterium atom from this position is less important than predicted for formation of an ion-neutral complex and complete loss of the positional identity of the hydrogen and deuterium atoms of the propyl group $\left(29 \% \mathrm{C}_{3} \mathrm{H}_{5} \mathrm{D}\right.$ loss and $71 \% \mathrm{C}_{3} \mathrm{H}_{4} \mathrm{D}_{2}$ loss). In addition, the loss of $\mathrm{C}_{3} \mathrm{H}_{4} \mathrm{D}_{2}$ from the $\left[\beta, \beta-\mathrm{D}_{2}\right]$-labeled ions is significantly less pronounced than expected for the ion-neutral complex pathway shown in Scheme 1, for the 2-isomer (on average $54 \%$ instead of the predicted $71 \%$ ). Evidently, part of the observed $46 \% \mathrm{C}_{3} \mathrm{H}_{5} \mathrm{D}$ loss (Table 2) arises by a pathway that involves the specific transfer of a deuterium atom from the $\beta$-position of the propyl group. A possible reaction would be a 1,5-hydride shift to the 2-position of the ring concomitant with propene loss and formation of the keto-species shown in Scheme 2. It should be emphasized, that the CID spectrum of the product ions of propene loss is similar to the spectrum obtained of the deuteronated 3-hydroxypyridine (see also Results and Figure 2). A competing reaction such as the 1,2-elimination with direct formation of the 3-hydroxypyridine (deuteronated at the nitrogen atom), therefore, cannot be excluded.

The occurrence of propene loss by another pathway than ion-neutral complex formation can reflect that the initial cleavage of the ether bond will lead to the zwitterion form of 3-hydroxypyridine (see Scheme 2). The relative stability of this form of 3-hydroxypyridine is uncertain but it is expected to be significantly less stable than the hydroxy form [46, 47]. As a result, the pathway involving ion-neutral complexes may be associated with a relatively high critical energy and allow other processes to be able to compete with this reaction pathway. Estimation of the relative extent of ion-neutral complex formation and, for example, the 1,5-hydride shift initiated propene loss is hampered, however, by the likely occurrence of kinetic isotope effects. For example, a statistical analysis (see Appendix) of propene loss from the metastable $[\mathrm{M}+\mathrm{D}]^{+}$ions of the $\left[\beta, \beta-\mathrm{D}_{2}\right]$-labeled 3-n-propoxypyridine suggest that 
<smiles>CC(C)c1ccc[n+]([O-])c1</smiles>
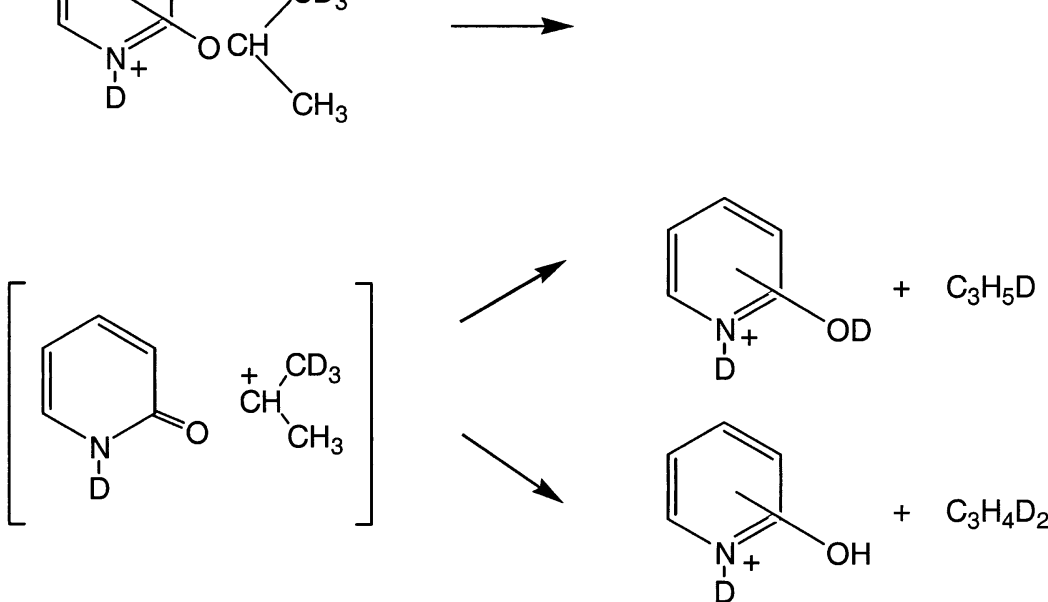

Scheme 3. Proposed mechanism of propene loss from the metastable $[\mathrm{M}+\mathrm{D}]^{+}$ions of the 2-, 3-, and $4-n$-isopropoxypyridines with intermediate formation of ion-neutral complexes and no loss of the positional identity of the hydrogen/deuterium atoms of the isopropyl carbenium ion.

about $24 \%$ of the ions dissociate by the pathway involving a 1,5-hydride shift (see also reference [48] for a review on composite atom interchange in gaseous ions). A similar analysis for the $\left[\alpha, \alpha-\mathrm{D}_{2}\right]$-labeled ions, indicates that slightly more ions (about $30 \%$ ) dissociate by such a mechanism, whereas a significantly larger part of the $\left[\gamma, \gamma, \gamma-\mathrm{D}_{3}\right]$-labeled ions $(45-50 \%)$ appears to react by the 1,5-hydride initiated propene loss as based upon the simplified statistical analysis. For the $\left[\alpha, \alpha-\mathrm{D}_{2}\right]-$ and $\left[\beta, \beta-D_{2}\right]$-labeled ions, the occurrence of an isotope effect in the 1,5-hydride shift could be held responsible for the suggestion that a lower fraction of the ions reacts by this pathway if the label is at the $\beta$-position. On the other hand, the apparent pronounced loss of propene by the 1,5 -hydride shift from the $\left[\gamma, \gamma, \gamma-\mathrm{D}_{3}\right]$-labeled species would tend to suggest the occurrence of a significant isotope effect in the ion-neutral complex pathway thus favouring the other reaction channel(s). Despite the limitations of the statistical analysis (as based on the absence of isotope effects), these considerations lead to the conclusion that more than one pathway is involved in propene loss from the 3-n-propoxypyridine.

The results for the metastable $[\mathrm{M}+\mathrm{D}]^{+}$ions of the 4-n-propoxypyridine appear to some extent to be intermediate to the findings for the 2-n- and 3-n-propoxypyridine isomers. In mechanistic terms, the results reveal a slight preference for the involvement of the $\beta$-position of the propyl group as exemplified by the observation that the average ratio between the losses of $\mathrm{C}_{3} \mathrm{H}_{5} \mathrm{D}$ and $\mathrm{C}_{3} \mathrm{H}_{4} \mathrm{D}_{2}$ (38:72) differs from the ratio (29:71) predicted for the sole occurrence of ion-neutral complex formation and randomization of the hydrogen and deuterium atoms within the propyl carbenium ion. For the 4-isomer, it is proposed that the competing process may be a 1,2-elimination in line with the expectation that the charge distribution within the $[\mathrm{M}+\mathrm{D}]^{+}$ions will disfavour a 1,5-hydride shift to the aromatic ring.
Even though the precise nature of the competing process is unknown, it is clear that it should involve a specific transfer of a hydrogen or deuterium atom from the $\beta$-position prior to propene loss.

For the isopropoxypyridines, the absence of the loss of $\mathrm{C}_{3} \mathrm{H}_{5} \mathrm{D}$ from the $[\mathrm{M}+\mathrm{D}]^{+}$ions of 2-, 3- and $4-\left(\mathrm{C}_{5} \mathrm{H}_{4} \mathrm{~N}\right)-\mathrm{OCD}\left(\mathrm{CH}_{3}\right)_{2}$ indicates that the positional identity of the hydrogen atom at the $\alpha$-position of the isopropyl group is retained during propene loss (Scheme 3). In the context of ion-neutral complex formation this observation suggests that the initial cleavage of the bond to the isopropyl group leads to an isopropyl carbenium ion with insufficient internal energy to undergo reversible 1,2-hydride shifts (see also reference [49]).

For the metastable $[\mathrm{M}+\mathrm{D}]^{+}$ions of the $\left[\beta, \beta, \beta-\mathrm{D}_{3}\right]-$ isopropoxypyridines the competing losses of $\mathrm{C}_{3} \mathrm{H}_{4} \mathrm{D}_{2}$ and $\mathrm{C}_{3} \mathrm{H}_{3} \mathrm{D}_{3}$ should occur to an equal extent in the absence of an isotope effect. By contrast, the observed average ratio is 33:67 from all the isomeric ions (Table 4). The experimental results indicate clearly the occurrence of a significant kinetic isotope effect of $\sim 2$ in propene loss from the ionized and labeled isopropoxypyridines. A similar kinetic isotope effect has been reported for the loss of propene from the metastable [M $+\mathrm{H}]^{+}$ions of $\mathrm{C}_{6} \mathrm{H}_{5} \mathrm{CH}\left(\mathrm{CH}_{3}\right) \mathrm{CD}_{3}$ and ascribed to the existence of a significant energy barrier between the $\left[\mathrm{C}_{6} \mathrm{H}_{6}\right.$ iso- $\left.\mathrm{C}_{3} \mathrm{H}_{7}^{+}\right]$and $\left[\mathrm{C}_{6} \mathrm{H}_{7}^{+} \mathrm{C}_{3} \mathrm{H}_{6}\right]$ complexes involved in the process [42]. For the present systems, it should be mentioned that the results can be interpreted also in terms of the occurrence of propene loss by a 1,2elimination as shown in Scheme 2 for the $[\mathrm{M}+\mathrm{D}]^{+}$ions of 3- $n$-propoxypyridine. Such a process may well be associated with a significant isotope effect. In other words, a distinction between the different possible pathways in propene loss from the $[\mathrm{M}+\mathrm{D}]^{+}$ions of the 
isopropoxypyridines cannot be reached on the basis of the present results.

\section{Conclusions}

Chemical Ionization of isomeric propoxypyridines with deuterium labeled reagents $\left(\mathrm{CD}_{3} \mathrm{OD}, \mathrm{CD}_{3} \mathrm{CN}\right.$, $\left(\mathrm{CD}_{3}\right)_{2} \mathrm{CO}$ and pyrrole- $\left.\mathrm{D}_{5}\right)$ yields abundant $[\mathrm{M}+\mathrm{D}]^{+}$ ions that expel only propene on the $\mu$ s time-scale. The main mechanism of propene loss is proposed to be the formation of ion-neutral complexes composed of a propyl carbenium ion and a hydroxypyridine in the keto form if the propoxy group is situated at the 2- or 4-position, whereas a zwitterion is formed if the propoxy group is at the 3-position in the parent compound. The subsequent proton/deuteron transfer is associated with an isotope effect that is particularly pronounced for the loss of propene from the $[\mathrm{M}+\mathrm{D}]^{+}$ of the isopropoxypyridines. In addition to the pathway involving ion-neutral complex formation, propene loss can involve: (1) A 1,5-hydride shift as indicated by the results of the 3-n-propoxypyridine and/or (2) a 1,2elimination type process as suggested for the 4- $n$ propoxypyridine.

\section{Acknowledgments}

The authors thank the Netherlands Organization for Scientific Research (SON/NWO) for continuing financial support. They acknowledge Mr. F. Pinkse for technical support and Mrs A. M. van der Burg for assistance during the synthesis of some of the labeled compounds.

\section{Appendix}

The relative extent of the losses of the partially labeled propene molecules from the metastable $[\mathrm{M}+\mathrm{D}]^{+}$ions of 3-n-propoxypyridines is analyzed by considering the complete loss of the positional identity of the hydrogen and deuterium atoms in combination with the occurrence of a specific transfer of a H/D atom from the $\beta$-position. For the $\left[\alpha, \alpha-\mathrm{D}_{2}\right]$-labeled 3- $n$-propoxypyridine, the statistical ratio is $2 / 7(29 \%) \mathrm{C}_{3} \mathrm{H}_{5} \mathrm{D}$ loss and $5 / 7(71 \%) \mathrm{C}_{3} \mathrm{H}_{4} \mathrm{D}_{2}$ loss, whereas the average experimental ratio between the losses of $\mathrm{C}_{3} \mathrm{H}_{5} \mathrm{D}$ and $\mathrm{C}_{3} \mathrm{H}_{4} \mathrm{D}_{2}$ is about 20:80. Upon the assumption that the 20\% loss of $\mathrm{C}_{3} \mathrm{H}_{5} \mathrm{D}$ only involves the formation of a $\left[\mathrm{C}_{5} \mathrm{H}_{4} \mathrm{DNO}\right.$ $\left.\mathrm{C}_{3} \mathrm{H}_{5} \mathrm{D}_{2}\right]^{+}$ion-neutral complex, the statistical ratio is matched if $50 \%$ of the total loss of propene (in the form of $\mathrm{C}_{3} \mathrm{H}_{4} \mathrm{D}_{2}$ ) arises from this channel. In conclusion, the remaining part of the $\mathrm{C}_{3} \mathrm{H}_{4} \mathrm{D}_{2}$ molecules $(30 \%$ of the total loss of propene) is formed by the specific transfer of a hydrogen atom from the $\beta$-position.

For the $[\mathrm{M}+\mathrm{D}]^{+}$ions of the $\left[\beta, \beta-\mathrm{D}_{2}\right]$-labeled $3-n-$ propoxypyridine the experimental ratio between the losses of $\mathrm{C}_{3} \mathrm{H}_{5} \mathrm{D}$ and $\mathrm{C}_{3} \mathrm{H}_{4} \mathrm{D}_{2}$ is approximately $46: 54$. For these $[\mathrm{M}+\mathrm{D}]^{+}$ions, the $54 \%$ loss of $\mathrm{C}_{3} \mathrm{H}_{4} \mathrm{D}_{2}$ is assumed to arise only by formation of ion-neutral complexes. As a result, the statistical ratio of $2 / 7 \mathrm{C}_{3} \mathrm{H}_{5} \mathrm{D}$ loss and 5/7 $\mathrm{C}_{3} \mathrm{H}_{4} \mathrm{D}_{2}$ loss is obtained if $22 \%$ of the total propene loss in the form of $\mathrm{C}_{3} \mathrm{H}_{5} \mathrm{D}$ is by this pathway. The remaining $24 \%$ of the total loss of propene (as $\mathrm{C}_{3} \mathrm{H}_{5} \mathrm{D}$ ) originates from a specific transfer of a $\mathrm{D}$ from the $\beta$-position. Similarly, the loss of $\mathrm{C}_{3} \mathrm{H}_{4} \mathrm{D}_{2}$ from the $[\mathrm{M}+\mathrm{D}]^{+}$ions of the $\left[\gamma, \gamma, \gamma-\mathrm{D}_{3}\right]-n$-propoxypyridens is assumed to originate only from ion-neutral complexes mediated processes as based on the experimental ratio 22:78 between the losses of $\mathrm{C}_{3} \mathrm{H}_{4} \mathrm{D}_{2}$ and $\mathrm{C}_{3} \mathrm{H}_{3} \mathrm{D}_{3}$. As a result, it is estimated that $49 \%$ of the total propene loss (in the form of $\mathrm{C}_{3} \mathrm{H}_{3} \mathrm{D}_{3}$ ) is expelled by the pathway involving a specific $H$-transfer from the $\beta$-position.

\section{References}

1. Harrison, A. G. Chemical Ionization Mass Spectrometry, 2nd ed.; CRC Press: Boca Raton, FL, 1992, pp 1-208.

2. Kebarle, P. Gas-phase Ion Thermochemistry Based on Ionequilibria from the Ionosphere to the Reactive Centers of Enzymes. Int. J. Mass Spectrom. 2000, 200, 313-330.

3. McMahon, T. B. Thermochemical Ladders: Scaling the Ramparts of Gaseous Ion Energetics. Int. J. Mass Spectrom. 2000, 200, 187-199.

4. Taft, R. W. Protonic Acidities and Basicities in the Gas Phase and in Solution: Substituent and Solvent Effects. Prog. Phys. Org. Chem. 1983, 14, 247.

5. Szulejko, J. E.; McMahon, T. B. Progress Toward an Absolute Gas-phase Proton Affinity Scale. J. Am. Chem. Soc. 1993, 115, $7839-7848$.

6. Kuck, D. Mass Spectrometry of Alkylbenzenes and Related Compounds 2. Gas-phase Ion Chemistry of Protonated Alkylbenzenes (Alkylbenzenium ions). Mass Spectrom. Rev. 1990, 9, 583-630.

7. Meot-Ner, M.; Sieck, L. W. Proton Affinity Ladders from Variable-Temperature Equilibrium Measurements. 1. A Reevaluation of the Upper Proton Affinity Range. J. Am. Chem. Soc. 1991, 113, 4448-4460.

8. Jasinski, J. M.; Brauman, J. I. Rates of Proton Transfer Between Pyridine Bases in the Gas Phase. Steric and Isotope Effects. J. Am. Chem. Soc. 1980, 102, 2906-2913.

9. Büker, H.-H.; Grützmacher, H.-F. A Fourier Transform-Ion Cyclotron Resonance Study of Steric Effects on Proton Transfer Reactions of Polyalkyl Benzenes. Int. J. Mass Spectrom. Ion Processes 1991, 109, 95-104.

10. Bouchoux, G.; Salpin, J. Y.; Leblanc, D. A Relationship Between the Kinetics and Thermochemistry of Proton Transfer Reactions in the Gas Phase. Int. J. Mass Spectrom. Ion Processes 1996, 153, 37-48.

11. Hunt, D. F.; Sethi, S. K. Gas-Phase Ion/Molecule IsotopeExchange Reactions: Methodology for Counting Hydrogen Atoms in Specific Organic Structural Environments by Chemical Ionization Mass Spectrometry. J . Am. Chem. Soc. 1980, 102, 6953-6963.

12. Lau, Y. K.; Kebarle, P. Substituent Effects on the Intrinsic Basicity of Benzene: Proton Affinities of Substituted Benzenes. I. Am. Chem. Soc. 1976, 98, 7452-7453.

13. Defrees, D. J.; McIver, R. T., Jr.; Hehre, W. J. The Proton Affinities of Phenol. J. Am. Chem. Soc. 1977, 99, 3853-3854.

14. Vulpius, T.; Hammerum, S.; Houriet, R. Protonation of Anisole and Halobenzenes. Adv. Mass Spectrom. 1989, 11, 578-579.

15. Audier, H.; Berthomieu, D.; Leblanc, D.; Morton, T. H. Multiple Protonation Sites in Aryl Ethers. Int. J. Mass Spectrom. 1998, 175, 133-147.

16. Bogdanov, B.; Matimba, H. E. K.; Ingemann, S.; Nibbering, N. M. M. Chemical Ionization of Phenyl $n$-Propyl Ether and Methyl Substituted Analogs: Propene Loss Initiated by Com- 
peting Proton Transfer to the Oxygen Atom and the Aromatic Ring. J. Am. Soc. Mass Spectrom. 1996, 7, 636-652.

17. Bogdanov, B.; Matimba, H. E. K.; Ingemann, S.; Nibbering, N. M. M. Chemical Ionization of Fluorophenyl n-Propyl Ethers: Loss of Propene from the Metastable $[\mathrm{M}+\mathrm{D}]^{+}$Ions. J. Am. Soc. Mass Spectrom. 1998, 9, 121-129.

18. Bogdanov, B.; van Duijn, D.; Ingemann, S.; Hammerum, S. Protonation of Fluorophenols and Fluoroanisoles in the Gas Phase: Experiment and Theory. Phys. Chem., Chem. Phys. 2002, 4, 2904-2910.

19. Benoit, F. M.; Harrison, G. Hydrogen Migrations in Mass Spectrometry. Org. Mass Spectrom. 1976, 11, 599-608.

20. Kondrat, R. W.; Morton, T. H. Ion Neutral Complexes from Protonated Propyl Phenyl Ethers. Gas-phase Solvolysis versus Elimination. Org. Mass Spectrom. 1991, 26, 410-415.

21. Kondrat, R. W.; Morton, T. H. Gas-phase Analogs of Solvolysis-The Conjugate Acid of Normal-Propyl Phenyl Ether. J. Org. Chem. 1991, 56, 952-957.

22. Jacquet, J. P.; Morton, T. H. Chemical Ionization of n-Propyl Phenyl Ether with $\mathrm{D}_{2} \mathrm{O}$ Reagent Gas. A Test of Statistical Models. J. Mass Spectrom. 1997, 32, 251-252.

23. Audier, H. E.; Morton, T. H. Ring Versus Oxygen Protonation in Metastable Ion Decompositions of Protonated Isopropyl Phenyl Ether. Int. J. Mass Spectrom. 1999, 187, 393-399.

24. Wolken, J. K.; Tureček, F. Modeling Nucleobase Radicals in the Gas Phase. Experimental and Computational Study of 2-Hydroxypyridinium and 2-(1H)-Pyridone Radicals. J. Phys. Chem. A 1999, 103, 6268-6281.

25. Hunter, E. P. L.; Lias, S. G. Evaluated Gas Phase Basicities and Proton affinities of Molecules: An Update. J. Phys. Chem. Ref. Data. 1996, 27, 413-656.

26. Cooks, R. G.; Beynon, J. H.; Caprioli, R. M.; Lester, G. R. Metastable Ions; Elsevier: Amsterdam, The Netherlands, 1976, pp 1-296.

27. Uggerud, E. Account: The 1995 Maccoll Lecture: Fifty Years of Metastable Ions. Experiment and Theory in the Study of Mass Spectrometric Fragmentation Reactions. Eur. J. Mass Spectrom. 1996, 2, 205-211.

28. Harrison, A. G.; Mercer, R. S.; Reiner, E. J.; Young, A. B.; Boyd, R. K.; March, R. E.; Porter, C. J. A Hybrid BEQQ Mass Spectrometer for Studies in Gaseous Ion Chemistry. Int. J. Mass Spectrom. Ion Processes 1986, 74, 13-31.

29. Zappey, H. W.; Ingemann, S.; Nibbering, N. M. M. Gas-Phase Ion-Molecule Reactions of the $\mathrm{CH}_{3} \mathrm{O}^{+}$Cation. J. Am. Soc. Mass Spectrom. 1992, 3, 515-517.

30. Molenaar-Langeveld, T. A.; Gremmen, C.; Ingemann, S.; Nibbering, N. M. M. Isomeric Dependence of the Formation of Ion/Neutral Complexes in Dissociation Reactions of Ionized Propoxypyridines. Int. J. Mass Spectrom. 2000, 199, 1-16.

31. Schmid, G. H.; Wolkoff, A. W. The Formation of Alkenes by the Thermal Elimination Reaction of N-Methyl-4-Alkoxypyridinium Iodides. Can. J. Chem. 1972, 50, 1181-1187.
32. Wilson, C. L. The Preparation of Organic Compounds Containing Deuterium, Dideuteromalonic Deuteroacid and Trideuteroacetic Deuteroacid. J. Chem. Soc. 1935, 492-494.

33. Bush, K. L.; Glish, G. L.; McLuckey, S. A. Mass Spectrometry/ Mass Spectrometry, Techniques and Application of Tandem Mass Spectrometry; VCH Publishers: New York, NY, 1988, pp 1-333.

34. Morton, T. H. Gas Phase Analogues of Solvolysis Reactions. Tetrahedron 1982, 38, 3195-3243.

35. McAdoo, D. J. Ion Neutral Complexes in Unimolecular Decompositions. Mass Spectrom. Rev. 1988, 7, 363-393.

36. Harrison, A. G.; Wang, J.-Y. Fragmentation of Deuteronated Aromatic Derivatives: The Role of Ion-Neutral Complexes. Int. I. Mass Spectrom. 1997, 160, 157-166.

37. McAdoo, D. J.; Morton, T. H. Gas-Phase Analogs of Cage Effects. Acc. Chem. Res. 1993, 26, 295-302.

38. Longevialle, P. Ion-Neutral Complexes in the Unimolecular Reactivity of Organic Cations in the Gas-Phase. Mass Spectrom. Rev. 1992, 11, 157-192.

39. Morton, T. H. The Reorientation Criterion and Positive-Ion Neutral Complexes. Org. Mass Spectrom. 1992, 27, 353-368.

40. Matimba, H. E. K.; Ingemann, S.; Nibbering, N. M. M. Competing Reactions Leading to Propene Loss from the Molecular Ions of Aryl n-Propyl Ethers. J. Mass Spectrom. 1996, 31, 609-622.

41. Herman, J. A.; Harrison, A. G. Effect of Protonation Exothermicity on the Chemical Ionization Mass Spectra of Some Alkylbenzenes. Org. Mass Spectrom. 1981, 16, 423-427.

42. Berthomieu, D.; Audier, H.; Denhez, J.-P.; Monteiro, C.; Mourgues, $\mathrm{P}$. $\left[\mathrm{C}_{6} \mathrm{H}_{6}, \mathrm{C}_{3} \mathrm{H}_{7}^{+}\right]$and $\left[\mathrm{C}_{6} \mathrm{H}_{7}^{+}, \mathrm{C}_{3} \mathrm{H}_{6}\right]$ Ion-Neutral Complexes Intermediates in the Reactions of Protonated Propylbenzenes. Org. Mass Spectrom. 1991, 26, 271-275.

43. Koblenz, T.; van Beelen, E. S. E.; Ingemann, S.; Hammerum, S.; in preparation.

44. Wolken, J. K.; Tureĉek, F. Heterocyclic Radicals in the Gas Phase. An Experimental and Computational Study of 3-Hydroxypyridinium Radicals and Cations. J. Am. Chem. Soc. 1999, 121, 6010-6018.

45. Tureček, F. Modeling Nucleobase Radicals in the Mass Spectrometer. J. Mass Spectrom. 1998, 33, 779-795.

46. Trikoupis, M. A.; Gerbaux, P.; Lavorato, D. L.; Flammang, R.; Terlouw, J. K. Hydrogen Shift Isomers of Ionic and Neutral Hydroxypyridines: A Combined Experimental and Computational Investigation. Int. J. Mass Spectrom. 2002, 217, 1-22.

47. Huq, F.; Yu, J. Q. Molecular Modeling Analysis: "Why is 2-Hydroxypyridine Soluble in Water but not 3-Hydroxypyridine?" J. Mol. Model. 2002, 8, 81-86.

48. Kuck, D. Half a Century of Scrambling in Organic Ions: Complete, Incomplete, Progressive, and Composite Atom Interchange. Int. J. Mass Spectrom. 2002, 213, 101-144.

49. Koch, W.; Liu, B.; Schleyer, P. v. R. Definitive Characterization of the $\mathrm{C}_{3} \mathrm{H}_{7}^{+}$Potential Energy Surface. J. Am. Chem. Soc. 1989, $111,3479-3480$. 